\title{
Techniques and Problems in Small Scale Production of Flour from Sweet Potato ${ }^{1}$
}

\author{
by Franklin W. Martin ${ }^{2}$
}

\begin{abstract}
Flours were made from mature storage roots of 26 varieties of sweet potato. Peeled roots were sliced or shredded and dried by solar heat with or without predrying cooking. Dried samples were milled, properties observed, and compostion tested. Samples, when cooked often developed disagreeable color, odor, and taste. Such characteristics could be avoided with antioxidants or by sufficient cooking. During microwave baking a large part of the starch was converted to reducing sugars, resulting in a flour too sweet for domestic purposes.
\end{abstract}

\section{INTRODUCTION}

Sweet potato roots, when harvested, have a limited storage life. In the tropics, common storage techniques often do not include washing, grading, any form of curing, or control of temperature or humidity. Storage life is often only a few weeks and post-harvest losses are large.

Techniques for curing sweet potatoes after harvest by a short period of high temperature and high humidity (1) have become standard in temperate regions. After curing, roots are stored at $13-15^{\circ} \mathrm{C}$ for periods of up to 1 year or more. Temperatures as low as $10^{\circ} \mathrm{C}$ result in reduced baking quality, increased decay, and shorter satisfactory storage life (5). Temperatures higher than $18^{\circ} \mathrm{C}$ result in earlier sprouting (10). During storage both positive and negative effects occur. The root is living, and respires. Thus, carbohydrate content steadily decreases (15). In some varieties there is a marked increase in sugar content as starches decompose. The usual opinion is that overall quality increases with curing, but then decreases slowly during storage (6).

The above curing and storage techniques are seldom used in the tropics, would be costly, might not be appropriate because of prevailing temperatures.

Processing is the way that harvested sweet potato roots can be converted into stable, long-lasting products (6). Canning and freezing, processes that are well developed in the temperate zones, may be too costly in tropical situations. Drying is appealing as a preservation process. By reducing water content a compact, easily stored and transportable material of high food value and versatility is obtained. Drying is potentially

\footnotetext{
${ }^{1}$ Manuscript submitted to Editorial Board September 20, 1983.

${ }^{2}$ Tropical Agriculture Research Station, Southern Region, Agricultural Research Service, Science and Education, U.S. Department of Agriculture, Mayagüez, P. R.
} 
the simplest and least costly process to preserve and eliminate storage loss of sweet potatoes.

In the United States large quantities of sweet potatoes were dried during World War II (6). Industrialized drying involves at least 11 different operations, listed by Spadaro and Patton (17) as storage, washing, preheating, peeling, trimming, slicing, blanching, pureeing, drying, grinding, and packaging. Drum drying of pureed sweet potato has become a reality and much research has been dedicated to its perfection. Sweet potato flakes may be prepared with added supplements such as soy flour (20) to increase their nutritional value. Recently spray drying has been tested in Trinidad in the preparation of sweet potato flour (13).

Cabinet drying, drum drying, and spray drying are highly technical processes that use large amounts of energy and add greatly to the cost of the final product. They are not suitable for home or very small scale use, and frequently they are not suitable to socio-economic realities of the tropics. Processes are needed in the tropics that are simple, require very few purchased inputs including energy, and that are suitable for home and small scale use as well as industrialization.

Solar drying is a common procedure in the tropics, used for such traditional crops as coffee and cocoa, and for the production of cassava chips, a sun dried product now widely used as animal feed (2). Various studies have been made to increase the efficiency of the technique and to reduce costs (18). Best results are obtained when the chipped cassava is on top of trays through which air can pass freely. A see-saw type solar dryer was designed by McLean (11) which involves minimum cost and maximum use of native materials.

Recently a very useful and simple solar dryer has been designed and tested at the International Potato Center, Peru (16). Cooked, shredded potatoes are placed on a shaded screen oriented towards the wind, and during 18 hours about $45 \%$ of the moisture is lost. During several hours of direct sunlight the following day, sun and wind dry the product to about $10 \%$ moisture. Thus, drying is accomplished in a convenient 24hour cycle. A simple plant was constructed using this technology to dry 1 ton per day of potatoes.

Dehydrated unpeeled, uncooked sweet potatoes have been ground by various commercial devises, and sieved to produce a fine flour (13). Treatment of the sliced materials with $1 \%$ sodium metabisulphite before drying was necessary to eliminate off-color and flavor. Flour is said to last for periods of several years. Such flours have been used in bread, at a dilution of 15 parts sweet potato flour to $85 \%$ wheat flour.

Hammed et al. (7) reviewed previous studies of sweet potato flour. In addition, flours were produced from peeled and unpeeled slices treated with sodium metabisulfite, and dried at $60^{\circ} \mathrm{C}$ in a forced draft oven. 
While the composition was analyzed, uses of the flour in cooking were not tested.

Plaut and Zelzbuch (12) prepared breads by adding 3 to $10 \%$ sweet potato flour to wheat flour. Details of the process are not given, but apparently the sweet potatoes were pressed to remove water, and then dried and milled. Only 6\% sweet potato flour could be used without lowering the quality of the bread.

Sweet potato flour is a common item in grocery stores in Perú, and is used for many household purposes. Luna de la Fuente (9) prepared flour by peeling, slicing, and drying at $50-60^{\circ} \mathrm{C}$ in a forced draft oven. Breads prepared with up to $10 \%$ sweet potato flour were considered acceptable.

These studies were made to develop a simple technique suitable for preparation of sweet potato flours in the home or on the small farm and to discover effects of cultivar on the flour-making process.

\section{MATERIALS AND METHODS}

Twenty six sweet potato cultivars or lines from the United States or Puerto Rico, produced during spring months in Puerto Rico, were used for some or all of these studies. All tests, observations and measurements were made in duplicate and averaged. Mature, large roots were hand washed, drained, and permitted to dry, hand peeled, and trimmed. Roots were sliced uniformly $(2-3 \mathrm{~mm}$ thickness) or shredded into $1 \times 2 \mathrm{~mm}$ shreds of indefinite length using a household rotary device. The slices were then dried as described below with or without cooking.

Slices and shred were cooked by three alternative techniques, boiling in water 20 minutes, pressure cooking at $15 \mathrm{lb} / \mathrm{in}^{2}\left(1 \mathrm{~kg} / \mathrm{cm}^{2}\right)$ for $15 \mathrm{~min}$, and by microwave oven at highest power level, 16 minutes.

The slices or shreds were distributed to a depth of $2-2.5 \mathrm{~cm}$ on fine galvanized screen trays and placed outdoors, under shelter, in a larger hardware cloth tray for 16-18 hours. During this time variable breezes reduced water content. The following morning the large tray was oriented perpendicular to the expected rays of the 10 o'clock sun, and exposed to direct sunlight for up to 5 hours (7:30-12:30). The slices and shreds were removed when brittle, weighed, crushed, and packed for storage in polyethylene bags. Slices usually required two full days of drying.

The dried material was ground finely in a household blender and passed through a baker's sieve (approx. max. diameter $1 \mathrm{~mm}$ ). The flour was weighed. Percent dry weight was calculated as the ratio of dry weight to wet weight of the sample. Flour yield was calculated as the percentage of the original root recovered as flour. Bulk density was measured as $\mathrm{g} /$ $\mathrm{cm}^{3}$. Notes were made of color, odor, and taste, as compared to wheat flour.

Samples of flour were tested for composition, dry weight basis, as 
follows: reducing and non-reducing sugars as well as proteins, were determined by methods of the Association of Official Analytical Chemists (8). Starch was determined by drying a sample in a forced draft oven at $60^{\circ} \mathrm{C}$, blending with 25 volumes water, permitting starch to settle out, redrying and reweighing.

The toxic substance ipomeamarone that occurs in sweet potatoes after wounding or infection was tested on silica gel plates by the method of Wood and Huang (21).

The flours were observed for color, odor, and flavor after mixing $10 \mathrm{~g}$ with $50 \mathrm{ml} \mathrm{H}_{2} \mathrm{O}$ and boiling $10 \mathrm{~min}$.

During processing the following notes were taken on a scale of 1-9 (9 is the most desirable level) by two judges who reached consensus: lack of oxidation, and lack of softening on cooking; ease of distribution; rapid drying, and ease of milling; and appearance, odor and flavor of the cooked sample. These notes were used to select and compare the two techniques reported here, raw verses microwave baked shred.

\section{RESULTS}

Various problems were encountered among cultivars that impeded the production of flour. Some of these problems were purely mechanical ones (small roots, irregular shapes, and insect damage). Some varieties when cut released latex which gummed up the slicer or shredder and impeded preparation. Immediately after slicing or shredding cut surfaces sometimes turned a dirty gray, a polyphenolic oxidation. Difference among varieties in internal color, latex released, and polyphenolic oxidation are summarized in table 1.

Dry weight of uncooked shredded sweet potatoes varied from 18.3 to $42.4 \%$ (table 1). Thus, the most dense varieties could have yielded more than twice as much flour per unit fresh weight as the least dense. The orange fleshed varieties appeared to be much less dense than the white to yellow fleshed varieties.

Slicing versus shredding influenced the ease of drying and of milling. Slices were easier to handle, but more difficult to dry, and once dry were more difficult to mill than shreds. Shreds could be cooked more uniformly but were more subject to breakdown and erosion especially on boiling or with the pressure cooker.

Predrying processing also influenced flour preparation. Uncooked slices and shreds were much easier to extend on drying trays, and dried much more rapidly than similar cooked materials. Boiled and pressure cooked shreds were much eroded and very difficult to handle. Reducing the time or intensity of these predrying process resulted in flours with disagreeable reactions, and thus these processes were considered inade- 
quate for small scale use. Microwave baked shreds appeared to be optimum for handling and drying.

The yield of flour produced (percentage of original storage root recovered as dry flour) depended not only on the dry weight of the root, but also on losses due to peeling and trimming (table 2). Yields ranged from 17 to $38 \%$ and tended to be slightly higher in microwave baked flours.

TABLE 1.-Internal color and dry weight of sweet potatoes, and problems affecting flour production

\begin{tabular}{|c|c|c|c|c|}
\hline \multirow[b]{2}{*}{ Cultivars or lines } & \multirow[b]{2}{*}{ Internal color } & \multirow{2}{*}{$\begin{array}{c}\text { Dry weight } \\
(\%)\end{array}$} & \multicolumn{2}{|c|}{ Problems in preparation } \\
\hline & & & $\begin{array}{l}\text { Amount of la- } \\
\text { tex }\end{array}$ & $\begin{array}{l}\text { Amount of oxi- } \\
\text { dation }\end{array}$ \\
\hline Bonara & Orange & 29.1 & Little & None \\
\hline Dominicana & Cream & 36.5 & Much & Much \\
\hline Frita & White & 31.2 & Little & Low \\
\hline Gem & Orange & 24.0 & None & None \\
\hline Jasper & Orange & 26.6 & None & None \\
\hline Jewel & Orange & 25.0 & Little & None \\
\hline Miguela & White & 32.0 & Much & Much \\
\hline Mina & Cream & 37.1 & Some & Much \\
\hline Papota & White & 38.4 & None & None \\
\hline Pelican Processor & Cream & 42.4 & Much & Much \\
\hline Picadito & White & 34.9 & Little & Medium \\
\hline Rojoblanco & Cream & 34.4 & Little & Medium \\
\hline Sedita & White & 39.8 & None & None \\
\hline Sulfur & Lt. yellow & 34.8 & Little & Low \\
\hline Travis & Orange & 18.3 & None & None \\
\hline Wart & Cream & 34.8 & Little & Low \\
\hline NC 172 & Orange & 33.8 & None & Medium \\
\hline NC 317 & Orange & 30.8 & None & Medium \\
\hline NC 719 & Orange & 30.4 & None & None \\
\hline SPT 6 & Yellow & 28.9 & Little & None \\
\hline SPT 7 & White & 33.2 & Much & Medium \\
\hline SPT 18 & Cream & 35.2 & Little & Medium \\
\hline SPT 47 & Lt. orange & 31.5 & Much & Medium \\
\hline W 119 & Orange & 33.4 & None & Low \\
\hline W 125 & Orange & 27.5 & Little & None \\
\hline W 149 & Orange & 28.1 & Little & None \\
\hline
\end{tabular}

Flours were predominantly whitish or cream colored, or slightly orange due to the carotene content of the storage root (table 2). Cooking increased the intensity of cream, yellow, and orange colors. The normal odor was pronounced, neutral, agreeable, even in the case of flours from uncooked sweet potatoes. Flours tended to be heavy, with bulk densities ranging from $0.65-91 \mathrm{~g} / \mathrm{ml}$ in the case of uncooked flour, and from 0.79 - 
1.04 in the case of flour from cooked sweet potatoes. Bulk density decreases as particle size decreases. Microwave cooking resulted in darker flours and in greater bulk densities.

In flours from uncooked sweet potatoes (table 3), starch accounted for the bulk of the flour, and varied from 69 to $85 \%$. Both reducing and nonreducing sugars were high in content, up to $16 \%$ in the case of reducing sugars, and up to $13 \%$ in the case of non-reducing sugars. Protein

TABLE 2.-Yield, color, and bulk density of flours from uncooked and microwave baked sweet potatoes

\begin{tabular}{|c|c|c|c|c|c|c|}
\hline \multirow[b]{2}{*}{ Variety } & \multicolumn{3}{|c|}{ Uncooked } & \multicolumn{3}{|c|}{ Microwave baked } \\
\hline & Yield $^{1}$ & Color & $\begin{array}{c}\text { Bulk } \\
\text { density }\end{array}$ & Yield & Color & $\begin{array}{c}\text { Bulk } \\
\text { density }\end{array}$ \\
\hline Bonara & - & - & - & 27.2 & Dark orange & 0.86 \\
\hline Dominicana & 34.3 & Gray cream & 0.88 & 37.2 & Gray & .91 \\
\hline Frita & - & - & - & 29.3 & Dark cream & .92 \\
\hline Gem & 17.7 & Cream & .77 & 25.1 & Gray orange & .79 \\
\hline Jasper & 23.1 & Light cream & .81 & - & - & 一 \\
\hline Jewel & 22.5 & Dark cream & .76 & 29.1 & Orange & .79 \\
\hline Miguela & 26.0 & Gray cream & .84 & 37.8 & Tan & .98 \\
\hline Mina & 32.1 & Gray cream & .87 & - & - & - \\
\hline Papota & - & - & - & 36.2 & Cream & 1.02 \\
\hline Pelican Processor & 36.7 & Light cream & .80 & - & - & 一 \\
\hline Picadito & 26.9 & Gray cream & .72 & 35.6 & $\operatorname{Tan}$ & 1.04 \\
\hline Rojoblanco & 25.7 & Gray cream & .86 & - & - & 一 \\
\hline Sedita & - & - & - & 37.0 & Dark cream & 1.01 \\
\hline Sulfur & 29.3 & Dark cream & .80 & - & - & - \\
\hline Travis & 21.5 & Light orange & .78 & 22.3 & Gray orange & .96 \\
\hline Wart & - & - & - & 30.7 & Tan & .90 \\
\hline NC 172 & 28.4 & Light orange & .82 & - & - & 一 \\
\hline NC 317 & 25.6 & Light orange & .83 & - & - & - \\
\hline NC 719 & 23.4 & Light orange & .65 & - & - & 一 \\
\hline SPT 6 & 25.2 & Cream & .87 & - & - & 一 \\
\hline SPT 7 & 23.3 & Light cream & .80 & - & - & - \\
\hline SPT 18 & 31.5 & Gray cream & .83 & - & - & - \\
\hline SPT 47 & 23.6 & Dark cream & .85 & - & - & - \\
\hline W 119 & 33.1 & Light orange & .75 & - & - & 一 \\
\hline W 125 & 22.3 & Light orange & .85 & - & - & - \\
\hline W 149 & 24.6 & Light orange & .74 & - & - & - \\
\hline
\end{tabular}

${ }^{1}$ Percent of original unpeeled sample recovered as flour.

contents ranged from 2.6 to $7.3 \%$. Cultivars and lines varied widely in composition.

In flours made from microwave baked sweet potatoes the amount of starch varied from 40 to $60 \%$, much less than in comparable flours from uncooked sweet potatoes (table 4). The levels of non-reducing sugars and of protein appeared to be uninfluenced by predrying processing. The 
TABLE 3.-Composition of flours (dry weight basis) prepared from non-cooked shredded sweet potatoes

\begin{tabular}{lrrrr}
\hline \multirow{2}{*}{ Variety } & \multicolumn{3}{c}{ Percent } \\
\cline { 2 - 5 } & Starch & $\begin{array}{c}\text { Reducing } \\
\text { sugar }\end{array}$ & $\begin{array}{c}\text { Non-reducing } \\
\text { sugar }\end{array}$ & Protein \\
\hline Dominicana & 78 & 1.9 & 7.3 & 3.6 \\
Gem & 70 & 16.1 & 7.6 & 4.1 \\
Jasper & 73 & 4.6 & 9.2 & 5.2 \\
Jewel & 69 & 9.1 & 10.9 & 5.3 \\
Miguela & 85 & 2.3 & 5.0 & 4.0 \\
Mina & 83 & 6.0 & 5.0 & 5.3 \\
Pelican Processor & 82 & 3.1 & 6.5 & 4.8 \\
Picadito & 81 & 1.9 & 11.5 & 2.6 \\
Rojoblanco & 80 & 2.2 & 9.5 & 5.1 \\
Sulfur & 76 & 3.2 & 10.9 & 7.2 \\
Travis & 71 & 9.4 & 11.2 & 4.6 \\
NC 172 & 78 & 2.5 & 9.2 & 6.4 \\
NC 317 & 76 & 6.4 & 10.6 & 6.2 \\
NC 719 & 70 & 7.4 & 10.6 & 6.5 \\
SPT 6 & 77 & 5.3 & 13.5 & 3.4 \\
SPT 7 & 78 & 5.9 & 12.0 & 2.6 \\
SPT 18 & 78 & 4.2 & 9.4 & 2.8 \\
SPT 47 & 78 & 8.8 & 6.0 & 7.3 \\
W 119 & 72 & 9.6 & 11.9 & 4.2 \\
W 125 & 77 & 3.8 & 10.7 & 7.4 \\
W 149 & 72 & 9.0 & 7.0 & 4.6 \\
\hline
\end{tabular}

TABLE 4.-Composition of flours (dry weight basis) prepared from microwave baked shredded sweet potatoes

\begin{tabular}{lcccc}
\hline & \multicolumn{4}{c}{ Percent } \\
\cline { 2 - 5 } Variety & Starch & $\begin{array}{c}\text { Reducing } \\
\text { sugar }\end{array}$ & $\begin{array}{c}\text { Non-reducing } \\
\text { sugar }\end{array}$ & Protein \\
\hline Bonara & 50.4 & 27.6 & 10.4 & 6.55 \\
Dominicana & 57.2 & 22.0 & 11.1 & 7.40 \\
Frita & 49.3 & 31.2 & 9.1 & 7.52 \\
Gem & 40.1 & 42.2 & 7.8 & 7.09 \\
Jewel & 48.4 & 34.4 & 11.6 & 5.59 \\
Miguela & 58.0 & 26.7 & 9.5 & 4.54 \\
Papota & 51.5 & 31.8 & 7.8 & 6.43 \\
Picadito & 59.6 & 23.1 & 10.6 & 4.04 \\
Sedita & 54.7 & 29.5 & 5.4 & 6.17 \\
Travis & 39.9 & 36.3 & 12.8 & 8.17 \\
Wart & 48.0 & 34.8 & 7.6 & 7.50 \\
\hline
\end{tabular}

levels of reducing sugars, ranging from 22 to $42 \%$, were much higher in flours from microwave baked than from uncooked sweet potatoes.

In several flours from uncooked sweet potatoes there were positive indications of the poisonous substance, ipomeamarone (possible traces 
found in flours of Jasper, Jewel, Miguela, Mina, SPT 6, and W 119). However, these traces were considered insufficient to make a positive identification. Flours produced from microwave baked sweet potatoes were free of such traces.

The cooking test in which a small sample of flour was boiled revealed a strong reaction which resulted in an ugly brown color, a disagreeable odor, and a taste that was nauseating to most people. Although this reaction was common to all 26 cultivars tested, it was influenced principally by predrying technique. Flour from dried, uncooked sweet potatoes always exhibited a strong reaction on cooking with water, which rendered these flours unsuitable for human use. This reaction was inhibited by small quantities of sodium metabisulfite or ascorbic acid added after preparing flour but before cooking.

Flours that were made from cooked sweet potatoes showed much less of the reaction and were better in color, odor, and taste than flours from uncooked sweet potatoes. However, the three cooking techniques did not yield equal results, nor did the two forms of preparation. Each cooking method had advantages and disadvantages. Boiling sufficiently to avoid polyphenolic reactions resulted in excessive softening and erosion, followed by difficulties in distributing the cooked sweet potato on trays as well as increased time necessary for drying. Pressure cooking resulted in the best product in terms of color, odor, and taste, but was difficult to expand from small sample preparation to the scope necessary for laboratory tests. Microwave baking resulted in a product easy enough to dry, and with fairly high quality.

\section{DISCUSSION}

Although the preparation of flour from sweet potato by simple methods suitable for other crops would appear to be a practical method for preserving sweet potato for later use, color, odor, and taste of such flours on cooking appear to rule out such usage. The fact that sodium metabisulfite and ascorbic acid inhibit this reaction suggests that it is due to oxidation, probably of polyphenols. Off flavors were described by Cassilly (3) as occurring in oxidized dehydrated sweet potato flakes. Accumulation of polyphenolics in sweet potatoes has been termed as hypersensitive reaction (14). Solvent extraction has been used to prepare flakes free of lipids and polyphenols (19).

It is possible that the toxic compound ipomeamarone is synthesized in shredded, uncooked sweet potatoes during the process of drying, just as it is in response to wounding and infection (4). Under these circumstances flours from uncooked sweet potatoes are not only inedible but also possibly hazardous. The use of ascorbic acid or sodium bisulfite, or both, may be feasible on an industrial scale to avoid the above reactions, but 
these are not suitable for household or small scale processing due to potential lack of control or abuse.

Because inactivation of the enzyme systems associated with off flavors and polyphenolic oxidation may require cooking apparatus not available at the home level, techniques developed here may not be suitable for small scale use.

Findings here conflict with those of Sammy (13) who reported the development of suitable flours from uncooked sweet potatoes. However, in his paper no explanation was given for varieties found to be unsuitable. Sammy also suggests that the low concentration (15\%) of sweet potato flour used might have masked disagreeable tastes and odors. ${ }^{3}$ It must be remembered that Sammy used $\mathrm{NaHSO}_{2}$ in his preparation of flour, which might have inhibited oxidation at critical moments.

These data also conflict with reports of the use of uncooked sweet potato flours for making bread in Peru (9). This author has not yet been able to obtain reliable data on the common flour making process of Peru.

The relatively high concentration of reducing sugars in uncooked sweet potatoes might have resulted from breakdown of starch during the drying period. However, the very much higher concentration of reducing sugars in microwaved baked sweet potatoes is well known in the case of conventional baking (6) and is now believed to be a non-enzymatic change. While the flours produced from microwave baked sweet potatoes are free from disagreeable color, taste and odor on cooking, nevertheless, the sugar content might be excessive for use of these flours as substitutes for other flours in baking.

\section{RESUMEN}

Se hicieron harinas de batatas (Ipomoea batatas) maduras de 26 variedades. Las batatas se rebanaron y se secaron con calor solar, ya cocidas o sin cocinar. Las muestras secas se molieron, se observaron sus propiedades y se analizó su composición. Las muestras cocidas frecuentemente mostraron color, olor y sabor desagradables. Se evitaron tales características usando antioxidantes o cocinando bien las muestras antes de secarlas. Durante la cocción por microhondas una gran parte del almidón se convirtió en azúcares reductores, lo que produjo una harina demasiado dulce para la mayoria de los usos domésticos.

\section{LITERATURE CITED}

1. Artschwager, E. and Starrett, R. C., 1931. Suberization and wound periderm formation in sweet potato and gladiolus as affected by temperature and relative humidity. $\mathrm{J}$. Agric. Res. 43: 353-64.

\footnotetext{
${ }^{3}$ Sammy, G. M., personal communication.

${ }^{4}$ Picha, D., personal communication.
} 
2. Booth, R. H. and Wholey, D. W., 1978. Cassava processing in Southeast Asia. pp. 711. In: Weber, E. J., Cock, H. H., and Chowinard, A., Eds, Workshop on Cassava Harvesting and Processing. Cali, Colombia. Proc. Ottawa, Canada, Int. Dev. Res. Cent.

3. Cassilly, J. P., 1971. An attempt to isolate the precursors of off flavor in oxidized dehydrated sweet potato flakes, Diss. Abst. Int. B. Sci. Eng. 32 (4): 2265B.

4. Catalano, E. A., Hasling, V. C., Dupuy, H. P., and Constantin, R. J. 1977. Ipomeamarone in blemished and diseased sweet potatoes (Ipomoea batatas). Agric. Food Chem. 25: 94-6.

5. Cooley, J. S., Kushman, L. J. and Smart, H. F., 1954. Effect of temperature and duration of storage on quality of stored sweet potatoes, Econ. Bot. 8: 21-8.

6. Edmond, J. B., 1971. Sweet Potatoes: Production, Processing, Marketing. AVI Publishing Co., Westport, Conn.

7. Hamed, M. G. E., Hussein, M. Y., Refai, F. H. and El-Samahy, S. K. 1973. Preparation and chemical composition of sweet potato flour. Cereal Chem. 50: 133-39.

8. Horowitz, W., 1980. Official Methods of Analysis. Association of Official Analytical Chemists, 13th ed, Washington, D.C.

9. Luna de la Fuente, R., 1960. Ensayo de panificación con mezclas de harina de trigo y tres variedades de camote, Bol. Trim. Exp. Agric. (Lima, Perú) 9 (3): 10-3.

10. McCombs, C. L. and Pope, D. T., 1958. The length of cure and storage on certain quality factors of sweet potatoes, Proc. Am. Soc. Hort. Sci. 72: 426-34.

11. McLean, K., 1972. Principles of sun drying with special reference to a see-saw dryer, Unnumbered Rep., Food and Agriculture Organization of the United Nations, Rome, Italy,

12. Plaut, M. and Zelzbuch, B., 1957. Use of sweet potatoes for flour and bread, Kfavim 8: $77-92$.

13. Sammy, G. M., 1970. Studies in composite flours. I. The use of sweet potato flour in bread and pastry making, Trop. Agric., Trinidad 47: 115-25.

14. Schulz-Schomburgh, E., 1975. Polifenoles en cultivos y su importancia agronómica. I. Reacciones de hipersensibilidad y la acumulación de los polifenoles en los tubérculos de Ipomoea batatas. Thesis. Universidad Central de Venezuela, Maracay, $205 \mathrm{pp}$.

15. Scott, L. E., and Mathews, W. A., 1957. Carbohydrate changes in sweet potatoes during curing and storage, Proc. Am. Soc. Hort. Sci. 70: 407-18.

16. Shaw, R., 1981. Solar drying potatoes. Appropriate Technology 7: 26-27.

17. Spadaro, J. J. and Patton, E. L., 1961. Precooked dehydrated sweet potato flakes, Food Eng. 33: 46-8.

18. Thank, N. C. and Lohani, B. N., 1978. Cassava chipping and drying in Thailand, pp. 21-25. In: Weber, E. J., Cock, J. H., and Chowinard, A., Eds. Workshop on Cassava Harvesting and Processing. Cali, Colombia. Proc. Ottawa, Canada, Int. Dev. Res. Cent.

19. Walter, W. M., Purcell, A. E., and Hansen, A. P. 1972. Auto-oxidation of dehydrated sweet potato flakes; the effect of solvent extraction on flake stability, J. Agric. Food Chem. 20 (5): 1060-63.

20. Walter, W. M., Jr., Purcell, A. F., Hoover, M. W. and White, A. G., 1978. Preparation and storage of sweet potato flakes fortified with plant protein concentrates and isolates, J. Food Sci. 43: 407-10.

21. Wood, G. and Huang, A., 1975. The detection and quantitative determination of ipomeamarone in damaged sweet potatoes, Ipomoea batatas. J. Agric. Food Chem. 23: $239-41$. 